\title{
KEBIJAKAN LAYANAN PENDIDIKAN UNTUK ANAK BERKEBUTUHAN KHUSUS (ABK) DI SATUAN PENDIDIKAN ANAK USIA DINI (PAUD)
}

\author{
Sapto Aji Wirantho \\ Pusat Kurikulum dan Perbukuan \\ Badan Penelitian dan Pengembangan Kementerian Pendidikan dan Kebudayaan \\ E-mail: saptoajiwirantho@gmail.com
}

Farah Arriani

Pusat Kurikulum dan Perbukuan

Badan Penelitian dan Pengembangan Kementerian Pendidikan dan Kebudayaan

E-mail: faraharriani@yahoo.com

Article received: 31 Desember 2016 Review process: 21 Februari 2017

Article published: 28 Februari 2017

\begin{abstract}
Abstrak
Penelitian ini mengkaji kebijakan pemerintah mengenai layanan pendidikan Anak Berkebutuhan Khusus (ABK) di satuan Pendidikan Anak Usia Dini (PAUD). Regulasi penyelenggaraan pendidikan ABK di PAUD belum operasional dan tersosialisasi dengan baik. Terdapatnya regulasi yang tumpang tindih antarkementerian menyebabkan layanan pendidikan $A B K$ di PAUD belum berjalan sebagaimana mestinya. Penelitian menggunakan metode kualitatif dengan pendekatan studi kasus. Data diperoleh melalui interview, observasi, studi dokumen, dan Focus Group Discussion (FGD). Penelitian dilaksanakan di 8 daerah yang sudah ditentukan yaitu Lampung, Jambi, Daerah Istimewa Yogyakarta, Jawa Timur, Bali, Nusa Tenggara Barat, Kalimantan Selatan, dan Sulawesi Tengah.
\end{abstract}

\section{Kata Kunci: ABK, AUD, Kebijakan, Layanan, PAUD}

\section{A. PENDAHULUAN}

Pemerintah menyadari pentingnya pembangunan sumber daya manusia adalah melalui pendidikan, hal ini dituangkan dalam Undang-Undang Dasar Negara Republik Indonesia 1945 pasal 31 ayat 1 "setiap warga negara berhak mendapat pendidikan." Bahkan hak memperoleh pendidikan mencakup untuk semua warga negara tanpa terkecuali. Hal ini dipertegas dalam Undang-Undang Sistem Pendidikan Nasional no. 20 tahun 2003 pasal 5 ayat 1 yaitu "setiap warga negara mempunyai hak yang sama untuk memperoleh pendidikan yang bermutu". Hak memperoleh pendidikan ini juga mencakup warga negara yang mengalami disabilitas seperti dinyatakan dalam pasal 2 yaitu "warga negara yang memiliki kelainan fisik, emosional, mental, 
intelektual dan atau/sosial berhak memperoleh pendidikan khusus." Mengacu pada undangundang tersebut terlihat bahwa pemerintah mengakui adanya hak untuk setiap anak berkebutuhan khusus $(\mathrm{ABK})$ untuk memperoleh kesempatan mendapatkan pendidikan yang sama dengan pada setiap anak.

Data Direktorat PAUDNI penerima bantuan operasional pendidikan (BOP) tahun 2014 jumlah ABK di 34 provinsi adalah 2.560 anak yang dilayani dari 622 jumlah lembaga. Jumlah ini tentunya belum mewakili keseluruhan ABK yang berusia dini. Masih banyak AUD dengan kondisi berkebutuhan khusus yang belum mendapatkan pendidikan. Terlebih jumlah ABK kian meningkat, meski hingga saat ini belum ada angka yang akurat. Menurut Fasli Jalal "Jumlah anak usia sekolah di Indonesia berdasarkan data BPS tahun 2005 sebesar 42.870 .041 jiwa. Jika asumsi PBB digunakan, maka ada 4,2 juta ABK di Indonesia.” (Republika, 17 Juli 2013). Sedangkan Hamid Muhammad dalam antara news (2015) menyatakan angka partisipasi bersekolah ABK masih rendah yaitu hanya sebesar 10-11\% dari jumlah total 1,6 juta ABK di tanah air.

Kebijakan-kebijakan yang mengatur layanan pendidikan untuk ABK di satuan PAUD telah lama bergulir namun hingga saat ini masih banyak ABK yang belum tersentuh PAUD. Selain itu pandangan negatif mengenai ABK dari kelurga dan masyarakat menyebabkan masih banyak orangtua yang menyembunyikan ABK. Hal ini terkesan ironis mengingat pendidikan merupakan tanggungjawab bersama antara keluarga, masyarakat dan pemerintah. Oleh karenanya penelitian ini bermaksud mengkaji kesesuaian antara kebijakan pemerintah yang telah ada, dukungan masyarakat dan orangtua terhadap pendidikan ABK di PAUD. Pertanyaan dalam penelitian ini terdiri atas: 1) bagaimana kebijakan ABK di PAUD, 2) bagaimana kerjasama pemerintah pusat dan daerah dalam implementasi kebijakan ABK di PAUD, 3) bagaimana dukungan keluarga dan masyarakat dalam layanan pendidikan ABK di PAUD?

\section{B. Metode Penelitian}

Penelitian ini menggunakan metode kualitatif dengan pendekatan studi kasus. Penelitian dilaksanakan di 8 daerah dipilih sesuai dengan kriteria tertentu, yaitu Daerah Istimewa Yogyakarta, Bali, Nusa Tenggara Barat, Kalimantan Selatan, Jambi, Lampung, Sulawesi Tengah, dan Jawa Timur. Penelitian dilaksnakan pada Maret - Juni 2015. Strategi pengumpulan data melalui wawancara, observasi, studi dokumen, dan FGD. Informan penelitian: pemangku kebijakan di pusat dan daerah, tenaga pendidik di satuan PAUD, orangtua, tokoh masyarakat, perguruan tinggi, LSM, NGO, bunda PAUD, organisasi terkait PAUD (HIMPAUDI, IGKTI), 
psikolog, dan terapis. Tehnik analisis data yang digunkaan adalah Miles dan Huberman. Langkah analisis data, meliputi reduction data, display data dan conclution drawing (verification).

\section{Penyampaian Hasil}

Pemerintah pusat telah mengembangkan kebijakan mengenai layanan pendidikan untuk ABK di satuan PAUD. Misalnya PP NO. 17 tahun 2010 tentang Pengelolaan dan Penyelenggaraan Pendidikan. Semangat penyelenggaraan pendidikan anak usia dini yang non dikriminasi dituangkan dalam Perpres no. 60 tahun 2013 tentang pengembangan PAUD holistic integratif. Melalui Perpres ini pemerintah melibatkan masyarakat untuk berpartisipasi aktif dalam pelayanan untuk pengembangan anak usia dini sehingga pelayanan yang diberikan PAUD dapat dijangkau dan terjangkau oleh seluruh lapisan masyarakat. Dapat kita simpulkan bahwa pemerintah telah menyiapkan layanan pendidikan untuk ABK di PAUD. Hal inipun dipertegas dalam Permendikbud No. 146 tahun 2014 tentang kurikulum 2013 PAUD pasal 10 yaitu “ Kurikulum untuk anak berkelainan atau berkebutuhan khusus merupakan Kurikulum 2013 Pendidikan Anak Usia Dini yang dikembangkan lebih lanjut sesuai dengan potensi dan kebutuhan anak. “

Kebijakan mengenai ABK bukan semata menjadi tanggungjawab dari kementerian pendidikan, pemerintah provinsi maupun pemerintah kab/kota semata namun melibatkan kerjasama lintas kementerian dan sektoral. Beberapa kementerian juga mengembangkan kebijakan mengenai layanan termasuk pendidikan untuk ABK di PAUD. Meski demikian kebijakan legal formal ini kurang disosialisasikan lintas sektoral sehingga kebijakan yang ada terkesan tumpang tindih dan tidak memiliki batas yang jelas. Secara garis besar hak anak berkebutuhan khusus untuk memperoleh pendidikan telah diakui dan dijamin oleh pemerintah. Sehingga pemerintah pusat mengeluarkan beberapa kebijakan yang terkait dan sesuai dengan tupoksinya untuk layanan pendidikan ABK di PAUD.

Beberapa aspek legal formal yang bersentuhan dengan layanan untuk ABK usia dini yaitu: UU no. 4 tahun 1997 tentang penyandang cacat, PP RI no. 39 tahun 2012 tentang penyelenggaraan kesejahteraan sosial, UU no. 36 tahun 2009 tentang Kesehatan, UU Nomor 23 Tahun 2002 tentang Perlindungan Anak, UU No. 39 tahun 1999 tentang Hak Azasi Manusia, Permendagri No. 19 tahun 2011 tentang Pedoman Pengintegrasian Layanan Sosial Dasar di Pos Pelayanan Terpadu. Di hampir semua daerah terlihat pelaksanaan layanan untuk ABK di PAUD berjalan sendiri-sendiri dan belum terintegrasi dikarenakan belum adanya sosialisasi lintas 
kementerian termasuk unit-unit dibawahnya, hal ini juga berimbas pada tidak adanya data akurat mengenai jumlah ABK.

Koordinasi antara pemerintah pusat dan daerah dalam mengembangkan layanan pendidikan untuk ABK di PAUD belum bersinergi dengan baik. Pemerintah pusat memberikan bantuan pendanaan (BOP) untuk pembelajaran ABK di PAUD baik dari Kemdikbud maupun dinas sosial, namun bantuan ini belum merata dikarenakan masih banyak daerah yang belum mengetahui kebijakan ini. Sebagian besar daerah belum memiliki kebijakan daerah terkait dengan penyelenggaraan pendidikan inklusi. Dari 8 sampel terpilih, hanya dua daerah yaitu Kota Yogyakarta dan Kota Banjarmasin yang memiliki kebijakan sendiri mengenai penyelenggaraan pendidikan inklusi untuk ABK di PAUD, meski menyatakan telah menjalankan pendidikan inklusi di PAUD dan jenjang pendidikan dasar serta menengah.

Umumnya masyarakat dan orang tua mendukung program layanan pendidikan untuk ABK di PAUD, meski tidak semua daerah memiliki program pelibatan nyata untuk masyarakat dan orang tua. Terlihat keterlibatan orang tua hanya sebatas dalam proses pembelajaran di satuan PAUD. Beberapa daerah memanfaatkan keberadaan bunda PAUD sebagai public figure untuk memasyarakatkan program layanan ABK di PAUD. Bahkan di Kota Yogyakarta Bunda PAUD ini juga merupakan motivator dan penggerak layanan pendidikan ABK di PAUD melalui berbagai kegiatan nyata. Meski di sebagaian besar daerah keberadaan bunda PAUD ini hanya sebatas icon politis. Hambatan pelaksanaan program ABK di PAUD keterbatasan dana, SDM, data yang akurat mengenai jumlah ABK dan rendahnya kesadaran di masyarakat tentang arti pentingnya pendidikan anak usia dini khususnya untuk ABK.

\section{Analisis dan Pembahasan Hasil Penelitian}

Pendidikan anak usia dini merupakan pendidikan awal yang diterima oleh seorang anak sebelum menyentuh pendidikan dasar. Dalam Permendikbud no. 146 tahun 2014 pasal 1 yaitu dinyatakan bahwa: Pendidikan Anak Usia Dini, yang selanjutnya disingkat PAUD, merupakan suatu upaya pembinaan yang ditujukan kepada anak sejak lahir sampai dengan usia 6 (enam) tahun yang dilakukan melalui pemberian rangsangan pendidikan untuk membantu pertumbuhan dan perkembangan jasmani dan rohani agar anak memiliki kesiapan dalam memasuki pendidikan lebih lanjut.

Mengacu pada Permendikbud tersebut dapat disimpulkan bahwa yang disebut dengan PAUD adalah sebuah program pendidikan yang ditujukan untuk anak sampai dengan usia 6 tahun. Pendidikan anak usia dini (PAUD) memiliki posisi yang sangat strategis bagi 
pengembangan sumber daya manusia, mengingat pada masa ini anak mengalami pertumbuhan dan perkembangan yang sangat pesat dalam berbagai aspek yaitu fisik, motorik, bahasa, sosial emosi dan kognitif. Pada masa ini juga terdapat masa keemasan yang menjadi ciri khas masa ini dan terjadi di masa 8 tahun awal kehidupan manusia. Masa ini hanya terjadi sekali dalam rentang kehidupan manusia sehingga tidak mengherankan apabila pemerintahpun menaruh perhatian besar terhadap anak usia dini dengan harapan sebagai starting point untuk membangun sumber daya manusia. Kehadiran PAUD tentunya sangat dibutuhkan oleh orang tua yang anak usia dini. Di sisi lain tidak semua anak mengalami proses perkembangan sesuai tahapannya, sebagian dari mereka mengalami gangguan perkembangan fisik dan motorik, kognitif, bahasa, dan sosial emosi yang dikenal dengan istilah anak berkebutuhan khusus, disingkat ABK.

Menurut Kirk (1970) yang dikutip oleh Efendi dalam pendidikan luar biasa atau pendidikan khusus, istilah penyimpangan secara ekplisit ditujukan kepada anak yang dianggap memiliki kelainan penyimpangan dari kondisi rata-rata anak normal umumnya, dalam hal fisik, mental maupun karakteristik perilaku sosialnya, atau anak yang berbeda dari rata-rata umumnya dikarenakan ada permasalahan dalam kemampuan berfikir, penglihatan, pendengaran, sosialisasi dan bergerak. Menurut Kustawan dan Meimulyani, anak berkebutuhan khusus adalah anak dengan karakteristik khusus yang berbeda dengan individu pada umumnya tanpa selalu menunjukan pada ketidak mampuan mental, emosi atau fisik. (2013: 29). Dalam PP No. 17 Tahun 2010 Pasal 129 ayat (3) dinyatakan bahwa "peserta didik berkelainan terdiri atas peserta didik yang: a. tunanetra; b. tunarungu; c. tunawicara; d. tunagrahita; e. tunadaksa; f. tunalaras; g. berkesulitan belajar; h. lamban belajar; i. autis; j. memiliki gangguan motorik; $k$. menjadi korban penyalahgunaan narkotika, obat terlarang, dan zat adiktif lain; dan l. memiliki kelainan lain.".

Seiring dengan bergulirnya deklarasi pendidikan inklusi yang dideklarasikan pada konferensi di Salamanca (1994) yang didahului dengan Konferensi Jomtien-Thailand (1990) tentang pendidikan untuk semua (education for all) dan penyediaan akses pendidikan dasar bagi semua anak di tahun 2000, pemerintah Indonesia memfasilitasi keberadaan ABK tak hanya di jenjang pendidikan dasar dan menengah, namun sejak usia dini. Hal ini telah dituangkan pemerintah dalam PP NO. 17/2010 tentang Pengelolaan dan Penyelenggaraan Pendidikan pasal 132 yaitu "Pendidikan khusus bagi peserta didik berkelainan pada jalur formal diselenggarakan melalui satuan pendidikan anak usia dini, satuan pendidikan dasar, dan satuan pendidikan 
menengah." Berbeda dengan penyelenggaraan pendidikan inklusi di jenjang pendidikan dasar dan menengah yang memang telah diatur dalam Permendiknas no. 70 tahun 2009.

Layanan pendidikan untuk ABK di PAUD dituangkan dalam Permendikbud no. 146 tahun 2014 tentang kurikulum PAUD dan Perpres no. 60 tahun 2013 tentang pengembangan PAUD holistic integratif. Melalui Perpres ini pemerintah melibatkan masyarakat untuk berpartisipasi aktif dalam pelayanan untuk pengembangan anak usia dini sehingga pelayanan yang diberikan PAUD dapat dijangkau dan terjangkau oleh seluruh lapisan masyarakat. Pelayanan ini juga bersifat nondiskriminatif sehingga seluruh anak usia dini dilayani tanpa terkecuali termasuk ABK.

Salah satu tujuan khusus Pengembangan Anak Usia Dini Holistik-Integratif adalah terselenggaranya pelayanan anak usia dini secara terintegrasi dan selaras antar lembaga layanan terkait, sesuai kondisi wilayah; dan terwujudnya komitmen seluruh unsur terkait yaitu orang tua, keluarga, masyarakat, Pemerintah dan Pemerintah Daerah, dalam upaya Pengembangan Anak Usia Dini Holistik-Integratif. Sehingga jelas terlihat bahwa dalam upaya pengembangan usia dini pemerintah pusat tidak bekerja seorang diri tetapi juga melibatkan pemerintah daerah, orangtua dan masyarakat. Hal ini sejalan dengan pemikiran Ki Hajar Dewantara yang dikenal dengan tri sentra pendidikan.

Compston (2004 : 310) menyatakan bahwa kebijakan publik dalam pendidikan terkait dengan peraturan dari pemerintah dalam ketentuan formal, pembiayaan dan atau peraturan dari layanan pendidikan dalam jangkauan tingkatan yang berbeda. Kebijakan publik di bidang pendidikan terkait dengan masalah pendanaan dan pelaksanaan, kebijakan akses dan prosedur evaluasi, kurikulum dan penilaian, perekrutan dan pelatihan guru. Aspek-Aspek yang tercakup dalam kebijakan pendidikan menurut Tilaar dan Nugroho dalam Rusdiana (2015:43) yaitu:

a. Keseluruhan hakikat manusia sebagai mahluk yang menjadi manusia di lingkungan kemanusiaan,

b. Penjabaran visi dan misi pendidikan dalam masyarakat tertentu,

c. Kesatuan antara teori dan praktik pendidikan. Kebijakan pendidikan meliputi proses analisis kebijakan, perumusan kebijakan, pelaksanaan dan evaluasi,

d. Validitas dalam perkembangan pribadi serta masyarakat yang memiliki pendidikan,

e. Ditujukan pada kebutuhan peserta didik,

f. Diarahkan pada terbentuknya masyarakat demokratis,

g. Penjabaran misi pendidikan dalam pencapaian tujuan-tujuan tertentu. 
h. Berdasarkan efisiensi. Kebijakan pendidikan harus dilaksanakan dalam masyarakat dan dalam lembaga-lembaga pendidikan,

i. Tidak berdasarkan kekuasaan, tetapi pada kebutuhan peserta didik,

j. Tidak berdasarkan institusi atau kebijakan yang rasional,

k. Kejelasan tujuan akan melahirkan kebijakan pendidikan yang tepat.

Mengacu pada uraian di atas dapat disimpulkan bahwa kebijakan pendidikan mencakup peraturan dari pemerintah, pendanaan, pelaksanaan, kebijakan akses dan prosedur evaluasi, kurikulum dan penilaian, perekrutan dan pelatihan guru.

Hal tersebut juga dibahas UNESCO dalam overcoming exclusion through Inclusive Approaches in Education (2003:25) yaitu pengembangan sistem pendidikan yang lebih inklusif juga membutuhkan pelatihan dan pelatihan ulang semua tenaga kependidikan. Kurikulum, penilaian dan evaluasi prosedur, layanan dukungan, mekanisme pendanaan dan kerangka kerja administrasi secara keseluruhan perlu disesuaikan untuk memfasilitasi pengembangan pendidikan inklusif..

Oleh karena itu, administrator dan manajer pendidikan dari kementerian pendidikan, pemerintah daerah, layanan kabupaten, LSM, NGO perlu diperkenalkan dengan prinsip-prinsip inklusi dan implikasinya terhadap sistem pada tingkat yang berberbeda.

Kebijakan mengenai pelayanan untuk ABK termasuk layanan pendidikan tak hanya berpusat di Kemetnerian Pendidikan namun juga berbenturan dengan tupoksi di beberapa kementerian berserta unit-unit dibawahnya seperti Kementerian Hukum dan Hak Azasi Manusia, Kementerian Sosial, Kementerian Kesehatan, Kementerian Pemberdayaan Perempuan dan Perlindungan Anak, Kementerian Dalam Negeri. Namun kebijakan yang dikeluarkan oleh masing-masing kementerian ini tidak bersinergi dengan baik. Misal: hak ABK untuk mendapatkan pendidikan selain merupakan kebijakan kemdikbud, kebijakan serupa juga dituangkan dalam UU no. 4 tahun 1997 tentang penyandang cacat pasal 6 ayat 1 yaitu "setiap penyandang cacat berhak memperoleh pendidikan pada semua satuan, jalur, jenis dan jenjang pendidikan. " Lebih lanjut pada ayat 4 dinyatakan bahwa "setiap penyandang cacat berhak memperoleh aksesibilitas dalam rangka kemandiriannya." Pada pasal 11 dinyatakan "setiap penyandang cacat mempunyai kesamaan kesempatan untuk mendapatkan pendidikan pada satuan, jalur, jenis dan jenjang pendidikan sesuai dengan jenis dan derajat kecacatannya." Sedangkan pada pasal 12 "setiap lembaga pendidikan memberikan kesempatan dan perlakuan 
yang sama kepada penyandang cacat sebagai peserta didik pada satuan, jalur, jenis dan jenjang pendidikan sesuai dengan jenis dan derajat kecacatan serta kemampuannya. “”

Kebijakan lainnya yaitu PP RI no. 39 tahun 2012 tentang penyelenggaraan kesejahteraan sosial pasal 2 ayat 2 yaitu " penyelenggaraan kesejahteraan sosial diprioritaskan kepada mereka yang memiliki kehidupan yang tidak layak secara kemanusiaan dan memiliki kriteria masalah sosial; a) kemiskinan, b) ketelantaran, c) kecacatan, d) keterpencilan, e) ketunaan sosial dan penyimpangan perilaku, f) korban bencana dan/atau: g) korban tindak kekerasan, eksploitasi dan diskriminasi”. Lebih lanjut pada pasal 6 ayat 1 dinyatakan bahwa:

"rehabilitasi sosial ditujukan kepada seseorang yang mengalami kondisi kemiskinan, ketelantaran, kecacatan, keterpencilan, ketunaan sosial dan penyimpangan perilaku serta yang memerlukan perlindungan khusus yang meliputi: a) penyandang cacat fisik, b) penyandang cacat mental. c) Penyandang cacat fisik dan mental, tuna susila, d) gelandangan, e) pengemis, f) eks penderita penyakit kronis, g) eks narapidana, h) eks pecandu narkotika, i) eks psikotik, k) pengguna psikotropika sindroma ketergantungan, 1) orang dengan Human Immunodeficiency Virus/Acquired Immuno deficiency Syndrome, m) korban tindak kekerasan, n) korban bencana, o) korban perdagangan orang, p) anak terlantar, q) anak dengan kebutuhan khusus.

Pasal 7 ayat 1 dinyatakan " rehabilitasi sosial diberikan dalam bentuk: a) motivasi dan diagnosis psikososial, b) perawatan dan pengasuhan, c) pelatihan vokasional dan pembinaan kewirausahaan, d) bimbingan mental spiritual, e) bimbingan fisik, f) bimbingan sosial dan konseling psikososial, g) pelayanan aksesibilitas, h) bantuan dan asistensi sosial, i) bimbingan resosialisasi, j) bimbingan lanjut dan/atau, k) rujukan. “

ABK juga dibahas dalam UU no. 11 tahun 2009 tentang kesejahteraan sosial, pasal 5 ayat 2 yaitu:

penyelenggaraan kesejahteraan sosial sebagaimana dimaksud diprioritaskan kepada mereka yang memiliki kehidupan yang tidak layak secara kemanusiaan dan memiliki kriteria masalah sosial, yaitu a) kemiskinan, b) ketelantaran, c) kecacatan, d) keterpencilan, e) ketunaan sosial dan penyimpangan perilaku, f) korban bencana dan/atau g) korban tindak kekerasan, eksploitasi dan diskriminasi.

Dalam UU no. 36 tahun 2009 tentang Kesehatan bab VII Kesehatan Ibu, Anak, Remaja, dan Penyandang Cacat pasal 131 ayat 2: "upaya pemeliharaan kesehatan anak dilakukan sejak anak masih dalam kandungan, dilahirkan, setelah dilahirkan dan sampai usia 18 tahun." Dan pada pasal 3 dinyatakan bahwa "upaya pemeliharaan kesehatan bayi dan anak sebagaimana dimaksud pada ayat 1 dan ayat 2 menjadi tanggungjawab dan kewajiban bersama bagi orang tua, keluarga, masyarakat dan pemerintah dan pemerintah daerah.” Lebih lanjut dalam pasal 139 ayat 
1 dinyatakan "upaya pemeliharaan kesehatan penyandang cacat harus ditujukan untuk menjaga agar tetap hidup sehat dan produktif secara sosial, ekonomis, dan bermartabat, (2) pemerintah wajib menjamin ketersediaan fasilitas pelayanan kesehatan dan memfasilitasi penyandang cacat untuk dapat tetap hidup mandiri dan produktif secara sosial dan ekonomis. " Pasal 140 yaitu 'upaya pemeliharaan kesehatan bagi lanjut usia dan penyandang cacat sebagaimana dimaksud dalam pasal 138 dan 139 dilakukan oleh pemerntah, pemerintah daerah dan/atau masyarakat. “

Pada UU No. 39 tahun 1999 tentang Hak Azasi Manusia - Bagian Kesepuluh Pasal 54 (Hak Anak) yaitu "setiap anak yang cacat fisik atau mental berhak memperoleh perawatan, pendidikan, pelatihan dan bantuan khusus atas biaya negara untuk menjamin kehidupannya sesuai dengan martabat kemanusiaan, meingkatkan rasa percaya diri dan kemampuan berpartisipasi dalam kehidupan bermasyarakat, berbamgsa dan bernegara."

Hak ABK juga dibahas dalam Undang-Undang Nomor 23 Tahun 2002 tentang Perlindungan Anak pasal 9:

a) Setiap anak berhak memperoleh pendidikan dan pengajaran dalam rangka pengembangan pribadinya dan tingkat kecerdasannya sesuai dengan minat dan bakatnya.

b) Selain hak anak sebagaimana dimaksud dalam ayat (1), khusus bagi anak yang menyandang cacat juga berhak memperoleh pendidikan luar biasa, sedangkan bagi anak yang memiliki keunggulan juga berhak mendapatkan pendidikan khusus.

Pasal 51" anak yang menyandang cacat fisik dan/atau mental diberikan kesempatan yang sama dan aksesibilitas untuk memperoleh pendidikan biasa dan pendidikan luar biasa, pasal 52 anak yang memiliki keunggulan diberikan kesempatan dan aksesibilitas untuk memperoleh pendidikan khusus."

Kemendagri juga mengeluarkan kebijakan mengenai layanan ABK dalam Peraturan Mentri dalam negeri no. 19 tahun 2011 tentang Pedoman Pengintegrasian Layanan Sosial Dasar di Pos Pelayanan Terpadu, pasal 7 , yaitu:

jenis layanan pembinaan gizi dan kesehatan ibu dan anak meliputi: a). suplementasi gizi mikro; b). penyuluhan gizi seimbang, konseling makanan bayi dan balita; c) pelayanan gizi meliputi pemantauan pertumbuhan, pemberian vitamin, pemberian makanan tambahan, penyuluhan, komunikasi informasi dan edukasi gizi; d) pemeriksaan tinggi badan dan berat badan, ukur lingkar lengan atas, tekanan darah, tinggi fundus uteri, pemberian tablet tambah darah, bila diperlukan imunisasi toxoid tetanus, konseling, pemeriksaan kehamilan bagi ibu hamil; e) layanan Keluarga Berencana berupa suntik, pil dan kondom; f) sosialiasi program perencanaan persalinan dan pencegahan komplikasi; 
g) pemberian Imunisasi dasar 0 - 9 bulan, h) pemantauan stimulasi deteksi dan intervensi dini tumbuh kembang pada usia 3, 6, 9 dan 12 bulan dan anak usia kurang dari 1 tahun minimal 2 kali dalam setahun; dan i) konseling dan penyuluhan mengenai perawatan bayi baru lahir, tanda-tanda bahaya pada bayi dan balita.

Lebih lanjut dalam ayat 5 Jenis layanan BKB sebagaimana dimaksud dalam pasal 5 ayat 2 yaitu: “ a) penyuluhan kepada keluarga/orang tua tentang kesehatan, gizi, perawatan, pengasuhan;b) stimulasi aspek-aspek perkembangan anak menggunakan alat permainan edukatif; dan c) rujukan bila anak mengalami gangguan tumbuh kembang." Sedangkan dalam ayat 6 dinyatakan "jenis layanan Pos PAUD sebagaimana dimaksud dalam Pasal 5 ayat (2) huruf f meliputi stimulasi pendidikan."

Pemerintah juga memperhatikan mengenai hak ABK dalam aksesibilitas ruang yang dibahas dalam UU no. 28 tahun 2002 tentang bangunan gedung, pasal 27 ayat 2 yaitu "kemudahan hubungan ke, dari, dan di dalam bangunan gedung sebagaimana dimaksud dalam ayat (1) meliputi tersedianya fasilitas dan aksesibilitas yang mudah, aman, dan nyaman termasuk bagi penyandang cacat dan lanjut usia, “ Sedangkan dalam pasal 31 ayat 2 dinyatakan "fasilitas bagi penyandang cacat dan lanjut usia sebagaimana dimaksud dalam ayat (1), termasuk penyediaan fasilitas aksesibilitas dan fasilitas lainnya dalam bangunan gedung dan lingkungannya."

Kebijakan yang tumpang tindih dan tidak bersinergi ini juga berimbas pada sulitnya pendataan $\mathrm{ABK}$ yang akurat karena setiap kementerian memiliki data tersendiri, selain itu masih banyak ABK yang tidak teridentifikasi. Kebijakan-kebijakan tersebut belum tersosialisasi secara meluas untuk unit-unit di bawahnya.

Terkait dengan layanan pendidikan untuk ABK di PAUD, kebijakan yang telah dikembangkan oleh pemerintah yang menjadi payung hukum penerimaan ABK di PAUD belum tersosialisasi dengan baik. Umumnya pemerintah daerah lebih familiar dengan UUD 45 pasal 31 dan UU No. 20 tahun 2003 tentang Sisdiknas pasal 15 sebagai acuan utama penerimaan setiap peserta didik tanpa terkecuali untuk mendapatkan layanan pendidikan. Selain itu Permendiknas no. 70 tahun 2009 tentang pendidikan inklusif bagi peserta didik yang memiliki kelainan dan memiliki potensi kecerdasan dan/atau bakat istimewa terlihat lebih terdengar gaungnya. Kurang tesosialisainya kebijakan layanan pendidikan untuk ABK di PAUD berdampak besar terhadap pemberian layanan pendididkan yang seharusnya diterima oleh anak. 
Koordinasi antara pemerintah pusat dan daerah dalam penyelenggaraan layanan pendidikan untuk ABK terlihat belum maksimal. Mengacu pada UU No. 20 Tahun 2003 tentang Sistem Pendidikan Nasional pasal 10 yaitu "pemerintah dan pemerintah daerah berhak mengarahkan, membimbing, membantu dan mengawasi penyelenggaraan pendidikan sesuai dengan peraturan perundang-undangan yang berlaku. “. Sehingga dapat disimpulkan pemerintah pusat dan daerah harus bersinergi dalam menyelenggarakan layanan pendidikan sesuai ketentuan yang berlaku. Kurang koordinasi juga membuat kebijakan mengenai pemberian bantuan dana operasional dari pusat untuk PAUD yang melayani ABK, dan dana bantuan seumur hidup untuk penyandang cacat banyak tidak diketahui oleh daerah.

Meski demikian jalinan kerjasama antara pemerintah pusat dan daerah dalam penyelenggaraan pendidikan ABK di PAUD telah di beberapa daerah. Misalnya: Di Kota Yogyakarta, kementerian kesehatan melalui puskesmas memiliki beberapa program terkait untuk penanganan anak usia dini ABK: screening (SDIDTK/ Stimulasi Deteksi Intervensi Dini Tumbuh Kembang) atau screening kesehatan, pelayanan terapi di RS negeri menggunakan BPJS, pelibatan kader posyandu sebagai lini depan untuk mendeteksi ABK melalui SDIDTK, layanan psikolog di setiap puskemas untuk deteksi dini ABK dan konsultan permasalahan tumbuh kembang dan penyediaan Guru Pembimbing Khusus di PAUD dengan memanfaatkan guru SLB sebagai pendamping dan konsultan. Penyediaan SDM merupakan tanggungjawab bersama antara pemerintah provinsi dan kab/ kota seperti yang terdapat dalam pasal 131 ayat 4 PP No. 17 Tahun 2010 tentang pengelolaan dan penyelenggaraan pendidikan yaitu " dalam menjamin terselenggaranya pendidikan khusus, pemerintah kab/ kota menyediakan sumber daya pendidikan yang berkaitan dengan kebutuhan peserta didik berkelainan." Sedangkan dalam ayat 6 dinyatakan " pemerintah provinsi membantu tersedianya sumber daya pendidikan yang berkaitan dengan kebutuhan peserta didik berkelainan pada pendidikan khusus.

Pemerintah daerah umumnya belum mengembangkan kebijakan layanan pendidikan untuk ABK, meski Kota Yogyakarta dan Banjarmasin telah membuat landasan legal formal terkait dengan penyelenggaraan pendidikan inklusi. Bahkan di Kota Yogyakarta, kebijakan legal formal ini mencakup pemberian layanan pendidikan ABK di PAUD hingga SMA dan pembentukan kelompok kerja (pokja) pendidikan inklusi Kota Yogyakarta yang berfungsi sebagai fasilitator dan mediator bagi semua pihak dalam implementasi pendidikan inklusi. Dinas Pendidikan Kota Banjarmasin memiliki program sekolah piloting utama pendidikan inklusi. Kebijakan yang dikembangkan di daerah mencakup SDM, pendanaan, kurikulum. Sedangkan 
untuk 6 daerah lainnya belum memiliki kebijakan daerah terkait dengan penyelenggaraan pendidikan inklusi di PAUD, meski menyatakan telah menjalankan pendidikan inklusi di PAUD dan jenjang pendidikan dasar serta menengah.

Penyelenggaraan layanan pendidikan untuk ABK di satuan PAUD umumnya belum dibarengi dengan penyediaan SDM yang sesuai oleh pemerintah daerah. Mayoritas pendidik di satuan PAUD tidak berlatar pendidikan khusus, satuan PAUD tidak memiliki GPK (Guru Pembimbing Khusus), shadow teacher dan tenaga ahli. Direktorat Pendidikan Anak Usia Dini menyatakan dalam bahan dan media pembelajaran pokok bahasan bahan anak berkebutuhan (2010: 38), komponen layanan untuk anak berkebutuhan khusus di kelompok bermain salah satunya adalah "pendidik dan tenaga kependidikan yang terdiri dari: 1) tenaga pendidik, 2) shadow teacher, 3) tenaga ahli (dokter, psikolog, terapis, pedagogi) dapat bermitra dengan lembaga lain. Pendidik dan tenaga kependidikan, yang terdiri dari: tenaga pendidik, shadow teacher, tenaga ahli (dokter, psikolog, terapis,pedagogi) dapat bermitra dengan lembaga lain. “

Dalam Permendiknas no. 70 tahun 2009, pemerintah kabupaten/kota memiliki kewajiban tak hanya untuk menyediakan GPK namun juga berkewajiban meningkatkan kompetensi bagi pendidik dan tenaga kependidikan. Pasal 10 ayat 1 dinyatakan "pemerintah kabupaten/kota wajib menyediakan paling sedikit 1 (satu) orang guru pembimbing khusus pada satuan pendidikan yang ditunjuk untuk menyelenggarakan pendidikan inklusif", pada pasal 3 "pemerintah kabupaten/kota wajib meningkatkan kompetensi di bidang pendidikan khusus bagi pendidik dan tenaga kependidikan pada satuan pendidikan penyelenggara pendidikan inklusif.

Dapat disimpulkan bahwa dalam penyelenggaraan layanan pendidikan untuk ABK, selain guru kelas, guru juga perlu bermitra dengan guru pembimbing khusus, shadow teacher, dokter, psikolog dan tenaga ahlinya agar layanan pendidikan yang diberikan sesuai dengan perkembangan dan kebutuhan ABK. Dan pemerintah bertanggungjawab dalam penyediaan SDM ini. Minimnya SDM berlatar belakang pendidikan khusus disikapi dengan berbagai kebijakan satuan pendidikan, misal melibatkan perguruan tinggi yang memiliki jurusan pendidikan khusus untuk melatih guru-guru PAUD menangani ABK, meski belum semua daerah terpilih memiliki universitas yang memiliki jurusan pendidikan khusus, bekerjasama dengan SLB sebagai guru khusus di PAUD maupun konsultan, bekerjasama dengan pusat terapi, memberdayakan orangtua/ pengasuh sebagai pendamping atau helper pada saat pembelajaran di kelas.

Untuk kebijakan mengenai pendanaan juga belum dimiliki oleh semua daerah. Hanya lima daerah yang menyatakan memiliki pendanaan untuk PAUD, yaitu Kota Yogyakarta, Kota 
Gianyar, Kota Mataram, Kota Banjarmasin, Kota Surabaya dan Kota Palu. Dana yang dianggarkan nominalnya berbeda oleh dinas pendidikan dituangkan untuk kebijakan yang beragam. Umumnya pendanaan digunakan untuk insentif para guru dan pelatihan, bahkan dinas pendidikan kota Banjarmasin memberikan beasiswa S1 untuk guru-guru PAUD yang belum meraih gelar kesarjanaaan, dana lainnya di alokasikan untuk sarana prasarana. Umumnya satuan PAUD belum memiliki sarana dan prasarana yang sesuai untuk ABK termasuk aksesibiltas lingkungan yang aman, nyaman dan memberi kemudahan kepada setiap ABK untuk melakukan aktivitas.

Satuan PAUD umumnya tidak menggunakan kurikulum khusus untuk ABK di PAUD. Hal ini sesuai dengan Permendikbud no. 146 Tahun 2014 pasal 10 juga telah ditegaskan bahwa "kurikulum untuk ABK adalah kurikulum 2013 PAUD yang dikembangkan sesuai dengan potensi dan kebutuhan yang dimiliki oleh anak." Manastas menyatakan (2014:65)" Kurikulum pendidikan inklusi menggunakan kurikulum sekolah regular (kurikulum nasional) yang dimodifikasi (diimprovisasi) sesuai dengan tahap perkembangan dengan mempertimbangkan karakteristik (ciri-ciri) dan tingkat kecerdasannya." Hal ini juga dibahas UNESCO (1999) dalam dalam Overcoming Exclusion through Inclusive Approaches in Education (2003: 16) beberapa elemen kunci untuk kurikulum yang bertujuan untuk mengembangkan pendidikan yang lebih inklusif:

1) Keluasan tujuan bersama yang ditetapkan untuk semua, termasuk pengetahuan, keterampilan dan nilai-nilai yang akan diperoleh

2) Struktur yang fleksibel untuk memfasilitasi merespon keragaman dan memberikan kesempatan beragam untuk praktik dan kinerja dalam hal konten, metode dan tingkat partisipasi

3) Assesment berdasarkan kemajuan individu

4) Keragaman budaya, agama dan bahasa peserta didik diakui dan

5) Konten, pengetahuan dan keterampilan yang relevan dengan konteks peserta didik

Untuk menyesuaikan dengan karakteristik anak maka dilakukan modifikasi kurikulum. Dalam pedoman penyelenggaraan pendididkan terpadu/inklusi $(2004 ; 32)$ dinyatakan bahwa ada beberapa teknik memodifikasi isi materi kurikulum untuk disesuaikan dengan kebutuhan peserta didik secara individual misalnya:

a) untuk peserta didik yang memiliki kelainan dan memiliki kecerdasan di atas normal (berbakat) materi dalam kurikulum sekolah regular dapat dimodifikasi dengan memperluas/ 
memperdalam, menambah materi yang ada di dalam kurikulum sekolah regular pada pokok bahasan berikutnya (percepatan), b) untuk peserta didik yang memiliki kelainan dan memiliki kecerdasan relative normal materi dalam kurikulum sekolah regular dapat tetap dipertahankan atau tingkat kesulitannya diturunkan sedikit, c) untuk peserta didik yang memiliki kelainan dan memiliki kecerdasan di bawah normal (peserta didik lamban belajar/tunagrahita) materi dalam kurikulum dapat dikurangi atau diturunkan tingkat kesulitan seperlunya atau bahkan dihilangkan bagian tertentu.

Setiap satuan PAUD mengembangkan sendiri kurikulum yang sesuai untuk ABK. Meski mayoritas responden di satuan pendidikan tidak melakukan modifikasi kurikulum dan tidak mengembangkan program khusus untuk ABK.

Kebijakan pendidikan untuk ABK di PAUD juga belum didukung secara penuh oleh masyarakat dan orangtua. Masyarakat belum memiliki kepedulian yang nyata akan ABK. Kerjasama masyakat dan keluarga sangat diperlukan dalam mendukung kebijakan pendidikan yang telah dikembangkan pemerintah. Hidayat (2013:25) menyatakan pengembangan lingkungan inklusif yang ramah terhadap pembelajaran (LIRP) terkait dengan berbagai yaitu kepala sekolah, guru, orang tua, dan masyarakat. (warga sekitar sekolah, tokoh masyarakat, dan para pengusaha atau pemilik usaha yang ada di sekitar sekolah). Keterlibatan masyarakat dalam mengembangkan LIRP karena masyarakat merupakan konteks dimana LIRP ini berada. Dalam kacamata sistem, input, proses dan output LIRP semuanya berasal, terjadi dan akan kembali ke masyarakat. Untuk itu, keterlibatan masyarakat dalam mengembangkan LIRP menjadi suatu prasyarat keberhasilan implementasi konsep ini.

Masyarakatpun dapat berkontribusi bagi keberhasilan pelaksanaan pendidikan inklusi yaitu: a) sebagai mitra pemerintah dalam mendukung terlaksananya model pendidikan inklusi, b) memperluas akses pendidikan dan pekerjaan bagi anak berkebutuhan khusus seperti membuka peluang kerja dan usaha bagi anak berkebutuhan khusus, c) membangun dan mengembangkan kesadaran akan hak anak untuk memperoleh pendidikan, d) melakukan kontrol sosial akan kebijakan pemerintah tentang pendidikan, membantu mengidentifikasi anak yang berkebutuhan khusus yang belum bersekolah di lingkungannya, e) sebagai tempat/wadah belajar bagi peserta didik, merupakan sumber informasi, pengetahuan dan pengalaman praktis, mendukung sekolah dalam mengembangkan lingkungan yang inklusif dan ramah terhadap pembelajaran, f) melakukan awareness campaign pada masyarakat yang belum mengetahui dan memahami pentingnya pendidikan inklusi (Pusat sumber SLB A, 2012:46). 
Daerah umumnya menggandeng publik figur dalam hal ini bunda PAUD untuk mensosialisasikan keberadaan ABK di PAUD. Bunda PAUD yang merupakan predikat yang diberikan kepada istri kepala pemerintahan (presiden, gubernur, bupati/ walikota, camat, kepala desa/lurah, atau wakilnya) atas perannya dalam mengembangkan program PAUD di wilayahnya. Sehingga disimpulkan bahwa gelar ini sebenarnya mengandung tanggungjawab dan kewajiban untuk mengembangkan PAUD di wilayahnya. Kehadiran bunda PAUD di daerah penelitian terkesan sebagai icon politik, belum terlihat adanya pemanfaatan bunda PAUD sebagai tokoh penggerak.

Meski demikian figure bunda PAUD kota Yogyakarta yang diwakili oleh istri walikota Yogyakarta dapat dikatakan sebagai penggerak PAUD termasuk ABK, tak hanya sekedar mencari donatur untuk pelatihan kader-kader posyandu mengenai $\mathrm{ABK}$, menjalin kerjasama dengan neuroscience untuk melatih kader-kader posyandu, tapi juga membuatkan modul aplikatif pendidik hingga membuat gerakan kader PAUD mengantar jemput ABK ke PAUD sehingga setiap ABK mendapat pendidikan.

Keterlibatan orang tua dalam pendidikan ABK di PAUD hanya sebatas keterlibatan dalam proses pembelajaran. Umumnya orangtua menyatakan kesulitan dalam mendapatkan informasi mengenai satuan PAUD yang menerima ABK. Informasi ini tidak tersosialisasi dengan baik pada satuan PAUD dan orang tua sehingga terkesan bersifat eksklusif dalam arti tidak semua orang mengetahui kebijakan ini. Tak mengeherankan di beberapa daerah terdapat ABK yang melanjutkan ke sekolah khusus padahal memiliki kemampuan intelegensi yang sama dengan AUD dikarenakan minimnya informasi dari dinas pendidikan. Orang tua berharap adanya panduan yang aplikatif sehingga orangtua ABK dan AUD juga mendapat informasi mengenai ABK dan dapat turut berperan aktif dalam mendidik ABK.

\section{E. Kesimpulan}

Penerimaan ABK di PAUD telah sebenarnya telah berjalan meski tanpa label inklusi dan tanpa ada payung hukum yang jelas seperti penyelenggaraan pendidikan inklusi di jenjang pendidikan dasar dan menengah. Hal ini menyebabkan layanan pendidikan yang diberikan untuk ABK belum berjalan sebagaimana mestinya. Kualifikasi tenaga pendidik yang tidak sesuai, tidak adanya guru pembimbing khusus (GPK), minimnya sarana prasana dan aksesibilitas menjadi potret buram pelaksanaan pendidikan inklusi di PAUD. Kondisi ini dipertajam dengan kebijakan mengenai ABK yang juga disandang di beberapa kementerian yang overlap dan tidak tersosialisasi dengan baik. Sehingga layanan yang diberikan tidak dapat bersinergi. 
Kebijakan mengenai ABK belum mendapat dukungan yang nyata dari masyarakat. Diperlukan edukasi masyarakat lewat media mengenai wajib belajar dimulai dari PAUD dan untuk ABK agar dapat ditangani sedini mungkin. Selain itu diperlukan pula kerjasama antara pemerintah pusat dan daerah untuk penyediaan sumber daya yang diperlukan dalam pendidikan inklusi, misal penganggaran untuk membiayai pelatihan guru maupun kerjasama dengan perguruan tinggi untuk melatih guru PAUD dan memasukkan mata kuliah pendidikan khusus sebagai mata kuliah wajib di program FKIP, sarana dan prasarana termasuk aksesibilitas untuk ABK. Diperlukan pula pembuatan panduan orangtua mengenai penanganan ABK sehingga orangtua terlibat dalam proses pembelajaran $\mathrm{ABK}$ di rumah.

\section{DAFTAR PUSTAKA}

Compston, Hugh. Handbook of Public Policy in Europe. New York: Palgriv Macmillian, 2004. Effendi, Mohammad. Pengantar Psikopedagodik Anak Berkelainan. Jakarta: Bumi Aksara, 2006 Direktorat Pendidikan Luar Biasa, Pedoman Penyelenggaraan Pendidikan Terpadu/Inklusi Buku 3 Pengembangan Kurikulum, Jakarta: Direktorat Pendidikan Luar Biasa, Dirjen Pendidikan Dasar dan Menengah Depdiknas, 2004

Hidayat, Deden Saepul. Pengembangan SLB sebagai Pusat Sumber (Resource Center). Jakarta: Luxima , 2013

Kementerian Negara Pemberdayaan Perempuan dan Perlindungan Anak RI. Peraturan Menteri Negara Pemberdayaan Perempuan dan Perlindungan Anak RI no. 10 Tahun 2011 tentang Kebijakan Penanganan Anak Berkebutuhan Khusus.

Kementerian Pendidikan Nasional. Bahan dan Media Pembelajaran Pokok Bahasan Anak Berkebutuhan Khusus pada Lembaga Kelompok Bermain, Direktorat Jendral Pendidikan Nonformal dan Informal, Direktorat PAUDNI. Jakarta: Direktorat PAUDNI, 2010.

Kementerian Pendidikan dan Kebudayaan. Data penerima bantuan operasional pendidikan (BOP) tahun 2014. Jakarta: Direktorat PAUDNI, 2014

Kustawan, Dedy dan Yani Meimulyani. Mengenal Pendidikan Khusus dan Pendidikan Layanan Khusus Serta Implementasinya, Jakarta: PT Luxima, 2013

Manastas, Lagita. Strategi Mengajar Siswa Tunanetra. Yogyakarta: Imperium, 2014 
Peraturan Presiden No. 60 Tahun 2013 tentang Pengembangan Anak Usia Dini Holistik Integratif, Kementerian Hukum dan Hak Asasi Manusia RI

Peraturan Menteri Dalam Negeri No. 19 tahun 2011 tentang Pedoman Pengintegrasian Layanan Sosial Dasar di Pos Pelayanan Terpadu

Peraturan Menteri Pendidikan dan Kebudayaan No. 146 tahun 2014 tentang Kurikulum 2013 PAUD

Peraturan Pemerintah No. 39 tahun 2012 tentang Penyelenggaraan kesejahteraan sosial

Peraturan Pemerintah No. 17 Tahun 2010 tentang Pengelolaan dan penyelenggaraan pendidikan

Pusat Kurikulum. Balitbang Kemdiknas Bunga Rampai Kurikulum, Buku Kedua, Jakarta: Pusat Kurikulum, Balitbang Kemdiknas, 2009.

Pusat Sumber SLB A. Pedoman Penyelenggaraan Pendidikan Inklusi. Jakarta: Pusat Sumber SLB A, 2012.

Rusdiana, H.A. Kebijakan Pendidikan Dari FIlosofi Ke Implementasi. Bandung: CV Pustaka Setia, 2015

Undang Undang Dasar Republik Indonesia tahun 1945

Undang-Undang RI no. 11 tahun 2009 tentang Kesejahteraan Sosial

Undang-Undang RI No. 20 tahun 2003 tentang Sistem Pendidikan Nasional, Jakarta: Inspektorat Jendral 2009

Undang-Undang RI No. 36 tahun 2009 tentang Kesehata

Undang-Undang RI No. 4 tahun 1997 tentang Penyandang Cacat

Undang-Undang No. 23 tahun 2002 tentang Perlindungan Anak

Undang-Undang No. 28 tahun 2002 tentang Bangunan Gedung

UNESCO. Salamanca 5 years on, Review of Unesco Activities in The Light of The Salamanca

Statement and Framework For Action On Special Needs Education. France: Place de Fontenoy, 1999

. Overcoming Exclusion through Inclusive Approaches in Education conceptual Paper,

Paris: Place de Fontenoy, 2003

. The Dakar Framework for Action Education For All: Meeting Our Collective

Commitments, France: Place de Fontenoy, 2000

http://www.antaranews.com/berita/527190/kemdikbud-angka-pertisipasi-bersekolah-anak-

berkebutuhan-khusus-rendah 
http://www.Republika.co.id/berita/nasional/umum/13/07/17/ mq2vp- jumlah anak berkebutuhan khusus di Indonesia tinggi 